\title{
The Steps of Technology Implementation in Education for Sustainable Development of Junior Highschool in Jakarta
}

\author{
F Doringin \\ Faculty of Humanities, Universitas Bina Nusantara, Jakarta, Indonesia \\ ferry.doringin@binus.ac.id
}

\begin{abstract}
The study has the purpose to find the technology-based-learning implementation model that enables learning delivery to be more effective for Junior High School students in Jakarta. This is the way to respond to the research problem that questions the difficulties of teachers in using educational technology effectively. The technology-based learning can promote the UN campaign for the Sustainable Development Goals (SDGs). The significance of the study is to help school and teachers to have a model of technology implementation in learning. Using a qualitative case study method, this research gathered data in a school in Jakarta that has enthusiasm and commitment to using technology in the learning. The researcher interviewed leaders and teachers coordinators, observed the steps of technology implementation and used literature and documentation review. As the findings, the implementation model needs a strong commitment from school leaders and foundations, personal and step-by-step mentoring to teachers, consistent training and practice, responsiveness to the world changes and student needs, encouragement of teachers to find their own tools, usage of standard operating system (SOP), monitoring and rigorous evaluation.
\end{abstract}

Keywords: SDGs, Technology-Based Learning, Technology Implementation

\section{INTRODUCTION}

A survey in a number of private schools states that one of the strengths of the private schools is in the facility [1]. The classroom is equipped with an LCD projector and almost all teachers are accustomed to using technology in the learning. A question arises if the technology already inherent in the learning. Has technology been used to support the effectiveness of the learning?The data found in some private schools when the research was started, said that the technology and internet weren't really integrated into learning. Some teachers didn't usepowerpointpresentation to its maximum functions. The use of powerpoint presentation was just like moving text into a presentation. Similarly, some teachers used movies to support the learning but still needed patterns, planning, and consistency. The problem was needed to be solved.

The purpose of this study is to find an implementation model of technology-based-learning for the Junior High School students in Jakarta. It will support teachers to be able to integrate technology into the learning and implement it consistently and effectively. The technologybased learning is the recommendation of UNESCO and UNICEFto reach the Education for Sustainable Development (ESD) as the part of the UN campaign for the promotion of the Sustainable Development Goals (SDGs)[2]. The technology is believed to develop the critical 
thinking, innovations, and collaborative decision-making. It also develops the skills, values, and attitudes that enable citizens (students) to respond to local and global challenges and global citizenship education. Through technology, schools design teaching and learning in an interactive, learner-centered way that enables exploratory, action-oriented and transformative learning. The positive role of technology can inspire learners to act for sustainability[3].

The study is very significant to find the effective delivery of the Junior High School students because the technology and the internet are part of their life. Their daily activities use technology and internet in almost all aspects [4]. The school and teachers can help students get their best achievement if they can deliver the lessons using the students' perspective that is the technology and the internet [5]. The study is significant for the teachers to reflect their learning, for the school to strategize their programs and help teachers follow the students' trend in technology and internet, and for the government to organize the effectiveness of learning.

\section{LITERATUR}

\subsection{Technology Reduces Costs and Improves Student Learning Outcomes}

Technology that can reduce costs in educational operations and can improve student learning outcomes. Vanderkam quotes Eli Broad who explains the 21st-century features that require technology in the learning. The technology will help the personalized learning that stops the era of one-size-fits-all. Personalized learning uses various styles in teaching-learning activities and fulfills students' needs and trends [6].

With technology, personalized learning provides many new opportunities, efficiency in economic aspect and personal strength that transform the teaching process of children. It pushes the creativity and innovation with new ways, methods, and results [7]. Some people compare it with 'disruption', a word that refers to the change that destabilizes but yields the fantastic improvements for the better quality. The good example of disruption is a car that disrupts the horse or email that disrupts the postal business. The technologyprovideddisruptive alternatives to solve the lower quality of learning like bad lectures disengaged students in the classroom, burned-out teachers, and bad educational environment [6].

The UNESCO document mentioned the role of technology to help design teaching and learning in an interactive and learner-centered way that enables exploratory, action-oriented and transformative learning and then inspire the learners to act for sustainability (Education for Sustainable Development) [3].

However, there is a potential problem in the field if the teachers are not using technology very intelligently at all in schools. Having access to technology and applying it effectively is the two different things. People don't benefit from technology if it is not used effectively in the classroom [6].

\subsection{Creativity and Innovation in Blended Learning}

The popular method in technology-based-learning is blended learning [8]. It is a combination of teachers and technology [9]. Blended learning changes the fit-for-all model to more personalized learning [6]. Blended learningrefers to a formal education program in which a student learns through online delivery of content and instruction and they can control over time, place, path, and/or pace. The learning varies and serves the needs of students[6]. 
According to Vanderkam, there are four basic strands of blended learning. The first is group rotation: Students move between different learning stations, including group collaborations that can be based on a fixed schedule or a teacher's discretion. The second is self-mixed: Students attend traditional classrooms with face-to-face instruction but supplement the learning with online courses during school or outside of school. The third is individual rotation: Teachers deliver most online instruction in an individually customized way but also provide small tutoring sessions. The fourth is online plus enrichment: Students use a full-time virtual school but they can choose to meet with instructors periodically for tutoring, exams, or enrichment [6]. Educators are still trying to figure out what works best for different kinds of students, and in which settings. Over the past few years, blended learning has grown and has given educators some teaching-learning possibilities [6].

There are four elements of blended learning. Firstly: Individualization. The technology gives many opportunities for personalized instruction to direct students at their own pace and style. The good computerized lessons help students to master concepts better. Some authors named personalized learning for the blended learning because teachers can teach in classical class but every studentfeels to be greeted because of technology usage [6].Secondly: improved feedback. There is a wisdom that practice makes perfect. However, ordinary repetition isn't enough. There is a need for teachers' feedback. The blended learning is optimized for learning through the effort of teachers to give feedback. [6].Thirdly: Teacher effectiveness and satisfaction. In a blended-learning, technology makes teaching easier and more efficient. Teachers can access many good materials and tools to support their teaching. The satisfaction may be the catalyst for the effectiveness of blended learning usage [6]. Fourthly: Cost control. One of the major attractions of blended learning is the possibility of eventually getting better results without extra spending, and perhaps even getting better results while spending less. Teachers don't need to buy but just use so many free tools, software, and data from the internet[6].

However, the digital learning doesn't eliminate the need for high-quality teachingblended learning can put too much emphasis on technology and stressed that technology is only a tool to achieve a different and better interaction between pupils and teachers. The use of technology and teachers in combination can help achieve better results in teaching. Both technology and teachers have their own strengths in the success of teaching. Computerized instruction delivers individualization and immediate feedback and teachers become tutors and mentors that strengthen the learning [8].

For some parents, the role of the teacher is unchangeable, although there are some popular programs, like homeschooling and distance learning [10]. Parents still send their children to formal schools because they want their children safe and staffed by competent adults while they're at work [6].

\subsection{Digital Native, Digital Immigrant, and Digital Aliens}

Prensky divides the human being into two kinds. First, the digital natives, those who are about 10 - 29 years old, commonly known as 'Generation Y'; it is said that they no longer need to learn how to use the internet. The website already exists in their bones. Second, the class of digital immigrants, aged 30-60 years old [11]. In addition to the two classifications of Prensky, Ira Kaufman called the third classification as the digital aliens. They are around 45 years old and above [12]. If digital natives born with the mouse, still baby can shift the touchscreen, then digital immigrants `already use Facebook and WhatsApp, digital aliens still struggle with sending a short message service (SMS) [11]. There is a situation when digital natives are 
taught by digital immigrants and it starts to become a big problem. If many Indonesian teachers and lecturers still use SMS, it means that the digital natives are taught by digital aliens [11].The situation will disturb the target of ESD that promotes the technology implementation creatively to inspire the sustainability [2].

\subsection{The 21st-Century Skills and Technology}

The 21st Century skills that are considered to strengthen social capital and intellectual capital, are commonly referred toas $4 \mathrm{C}$ : communication, collaboration, critical thinking and problem-solving, and creativity and innovation [13]. Operationally, 4C is outlined in four step categories: First, the way of thinking, including creative, innovative, critical, problem solving, decision-making, and proactive learning. Second, how to work, including communicating, collaborating, working in teams. Third, the way of life as a global citizen as well as local; and fourth, a tool for developing 21st-century skills, namely information technology, digital networks, and literacy. Technology is considered very appropriate tools to answer the needs of students in the 21 st century [14].

So, technology help teachers get better results and make their jobs more satisfying and they can serve the students with technology savvy if they develop their skills in technology [15].

\section{METHODS}

The qualitative case study is used as the method of the research. The researcher interviewed three school leaders and four teachers' coordinators, observed some teachinglearning activities, learned the evaluation, and studied some reports. The good momentum was coming after the school made their strategic planning and was ready to implement the technology-based-learning. It was the part of the school development program. Every semester, the teachers followed these steps: training, personal assistance, supervision, and evaluation.The teachers were trained with various technology-based-learning, including Facebook, Instagram, powerpoint, movie maker, and so on. After getting the training in the technology, every teacher chose one of the technologies, learned more, explored the application, and then implemented it. In the implementation process, the teachers were also supported with personal assistance to explore the technology they choose. They were supervised in the classroom. After supervision, every teacher would be called by the supervisors to discuss their classroom process and management. They got input and evaluation so they could improve their teaching. All data from the interviews, observations, and reports were used to analyze the use of technology in the learning.

\section{RESULT AND DISCUSSION}

The result of this research said that (1) Technology-based-learning as the policy of institution: Make technology as an advantage. (2) Teachers have the flexibility to choose software or technology types. (3) Teachers are assisted specifically and step by step in the implementation of technology-based-learning. (4) Improve the skills in technology-basedlearning through never-stop practicing. (5) Handle the resistance wisely but continue to walk. Never stop the process. 


\subsection{Technology-Based-Learning as the Commitment of the Institution}

Technology-based-learning in the school was started with the socialization of the school concept. The school leaders tried to convince the teachers that technologywas so powerful in this century. The teachers were not only encouraged to realize and acknowledge it but also they were encouraged to be grateful, enjoy, and take part in the use of technology.

The teachers were also aware of the models of students they would serve. Their students were 21st-century students who were digital natives. The school management encouraged that the current situation put the teachers in the position of digital immigrants, even further Ira Kaufman says that today's teachers were digital aliens. By realizing this position, teachers were motivated to use technology as a means of learning that couldn't be negotiable.

The teachers were encouraged to arrive at the realization that their class would be boring and dried and they would have difficulty if they didn't use the technology. The school management posed the fact that the technology could solve the difficulties that were faced by the teachers. In the Indonesian context, with the government's emphasis on 21st-century skills and Higher Order Thinking Skills, the technology-based-learning gained the momentum.

With that momentum, the school management officially declared that the technology was the commitment of all the citizens of the school. The technology-based-learning served as the way of the school to achieve its excellence and all teachers needed to practice it.

\subsection{Resistance as the Part of the Process. Be Wise And Don't Stop in Your Process}

Resistance was a process that usually occurred in a change. It needed consistency from school management so that resistance could be answered well and wisely. Resistance should not spread and cause turmoil. Therefore, resistance would be responded to immediately. It needed a strong authority to respond as well as the wisdom to embrace those who were resistant. Never let our process stop because a resistant person was left untreated.The school management began to strengthen the group of committed teachers who were feeling the benefits of the program. This group needed to be encouraged to be solid; even able to attract other teachers. Special arrangements were needed so that the teachers who were committed to developing themselves in technology were appreciated.

\subsection{Teachers Have the Flexibility to Choose Software or Technology Types}

One of the reasons why teachers were resistant to change programs was because they faced a radical change, something new in their life. Teachers usually complained that the field to be entered was too difficult or too confusing. The school had to start with what the teachers already had. Because of technology-based-learning offered implementation in a variety of programs, such as Facebook, movie maker, or other programs, so, teachers were given the flexibility to find programs that were familiar with them. Maybe they already used the program in their daily activities. From there, direct them to practice it in the teaching activities. If they were already adept at using certain programs in their daily lives, then they would be easy to use it in teaching. They also became excited about departing from what they had. It helped them to start and deepen it.

\subsection{Teachers were Assisted Specifically and Step by Step in The Implementation of Technology-Based-Learning}

Another thing that became the reason for resistance was the difficulty in implementing certain technologies. This was very good if they were trained but also accompanied in 
implementing that knowledge in learning. They were specifically accompanied to solve their problems immediately. Moreover, they were accompanied to practice step by step technologybased learning.The trainers were ready to be contacted at any time. In addition, the trainers could come to school immediately when they found that certain teachers were struggling to achieve the planned implementation targets.

\subsection{Teachers were Assisted Specifically and Step by Step in the Implementation of Technology-Based-Learning}

The technology-based-learning is a skill. If you stop to practice, you will lose your technological skills. Do not stop to practice. After training and then success in using their own choice technology, the teachers still use the technology regularly. The school supported them through personal assistance. The school also conducted the regular supervision and evaluation. It was required that the practice of teaching using technology was carried out routinely with clear guidance and clear targets. With that, the teachers would continue to use the technology they mastered. If they rarely even stop using it, then the cost to start it would be very high. They had to start again from the scratch.

\subsection{Technology-Based-Learning Doesn't Replace the Role of Teachers. the Need for Teachers to Still Develop Their Main and Basic Competence}

Technology never replaces the role of teachers. Technology doesn't make teachers lose their main and basic competencies, including competency in the opening and closing the learning, classroom management, goal achievement in learning, innovative delivery, and good assessment.In the observation, the teachers looked competent in their areas. They also looked full of confidence. However, some teachers only focused on material transfer and didn't think about the whole process like opening and closing the learning, reinforcement, assessment, and made a good summary and final statement in the end.The opening of the class is important because students need an explanation of the daily process. The good class opening helps student concentrate, focus, and cooperate to make the good process run well. The summary and final statement, in the end, is also important because the students will get reinforcement and knowledge to be brought into their home. The teachers also need to give the context to the learning. They have to give good examples that refer to the daily life of students.

\subsection{Challenges}

The first challenge is the mindset. Some teachers think that the ability to use technology is only owned by the young generation. They don't need to learn and use technology because of their ages. Internet access issue is another reason to refuse the use of internet [16]. Another challenge is the appropriate program and technology for the young generation and how to anticipate the negative impacts of technology.

\section{CONCLUSION}

There is a need for the school in Jakarta to find a technology-based-learning model that enables learning delivery to be more effective for students. The problem is the difficulty of teachers to use the technology effectively. It is the big problem because the technology is the part of the life of the students in the generation. The model must start with the strong 
commitment of the leaders. Then, the leader must support the teachers with personal and stepby-step mentoring, consistent training and practice, and the good system for guidance, monitoring, and evaluation. It is important to integrate the technologyuse in education as the part of the effort to reach the Education for Sustainable Development (ESD) and also Sustainable Development Goals (SDGs).

As a recommendation, it is important for the school to use technology in the teachinglearning activities because to serve the students better. The government, school, and teachers need to prepare the good process of the implementation, including mindset change, training, personal assistance and coaching, and regular evaluation.

\section{References}

[1] A. C. Kuntoro, "Tantangan Penyelenggaraan Pendidikan Katolik yang Unggul, Inovatif, Bermutu Reforming Pedagogy," in Prosiding Seminar Nasional Reforming Pedagogy, 2016.

[2] A. Opoku and P. Guthrie, "Education for sustainable development in the built environment," Int. J. Constr. Educ. Res., vol. 14, no. 1, pp. 1-3, Jan. 2018.

[3] UNESCO, "Education for Sustainable Development Goals - Learning Objectives," UNESCO, 2017. [Online]. Available: https://www.unesco.de/sites/default/files/201808/unesco_education_for_sustainable_development_goals.pdf.

[4] N. V. Smith, "Face-to-face vs. Blended Learning: Effects on Secondary Students 'Perceptions and Performance," Procedia - Soc. Behav. Sci., vol. 89, pp. 79-83, 2013.

[5] B. Martinsen, C. Jackson, and H. Whitehouse, "Student Perceptions of Using Blended Learning in Secondary Science," in Official Conference Proceedings of the European Conference on Technology in the Classroom 2015, 2015, pp. 97-110.

[6] L. Vanderkam, Blended Learning: A Wise Giver's Guide to Supporting Tech-Assisted Teaching. Washington, D.C: The Philanthropy Roundtable, 2013.

[7] E. Szeto, “A Comparison of Online/Face-to-face Students' and Instructor's Experiences: Examining Blended Synchronous Learning Effects," Procedia - Soc. Behav. Sci., vol. 116, pp. 4250-4254, 2014.

[8] M. Kaur, "Blended Learning - Its Challenges and Future," Procedia - Soc. Behav. Sci., vol. 93, pp. 612-617, 2013.

[9] S. Istiningsih and H. Hasbullah, "Blended Learning, Trend Strategi Pembelajaran Masa Depan," J. Elem., vol. 1, no. 1, p. 49, Mar. 2015.

[10] A. A. Okaz, "Integrating Blended Learning in Higher Education," Procedia - Soc. Behav. Sci., vol. 186, pp. 600-603, 2015.

[11] M. Prensky, "Digital Natives, Digital Immigrants Part 2: Do They Really Think Differently?," Horiz., vol. 9, no. 6, pp. 1-6, Nov. 2001.

[12] I. Kaufman, "Are You a Digital Alien, Digital Immigrant, or Digital Native? ...Marketing to the Digital WHO...," Social Media Today, 2011. [Online]. Available: https://www.socialmediatoday.com/content/are-you-digital-alien-digitalimmigrant-or-digital-native-marketing-digital-who.

[13] S. Zubaidah, "Keterampilan Abad Ke-21: Keterampilan yang Diajarkan melalui Pembelajaran," in Seminar Nasional Pendidikan: Isu-isu Strategis Pembelajaran MIPA Abad 21, 2017, no. June.

[14] E. Yuni Wijaya, D. Agus Sudjimat, and A. Nyoto, "Transformasi pendidikan abad 21 sebagai tuntutan pengembangan sumber daya manusia di era global," in Prosiding Seminar Nasional Matematika, 2016.

[15] M. Prensky, From Digital Natives to Digital Wisdom: Hopeful Essays for 21st 
Century Learning. 2590 Conejo Spectrum, Thousand Oaks California 91320 United States: Corwin Press, 2012.

[16] I. Yapici and H. Akbayin, "High school students' views on blended learning," Turkish Online J. Distance Learn., vol. 13, no. 4, pp. 125-139, 2012. 